\title{
Periods of weed interference in cowpea crop in the semi-arid of Minas Gerais, Brazil
}

\author{
Marlon Lopes Lacerda ${ }^{1} \oplus$, Ignacio Aspiazú1 ${ }^{\oplus}$, Abner José de Carvalho ${ }^{1} \oplus$, Alexandre Ferreira da Silva ${ }^{2}$, \\ Evander Alves Ferreira ${ }^{3}$, Andrey Antunes de Souza ${ }^{1}$, Marcos Lopes de Campos ${ }^{1} \odot$, \\ Cleiton Fernando Barbosa Brito ${ }^{1}[$

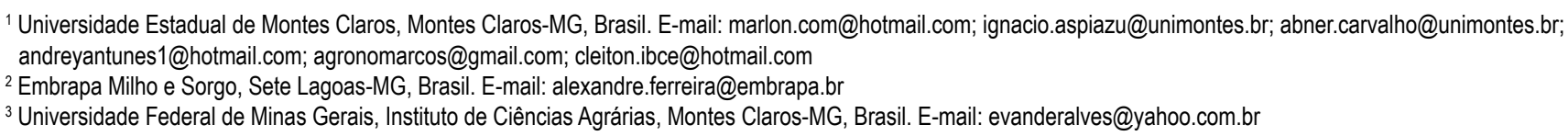

ABSTRACT: Weed interference is one of the main limiting factors in the cowpea yield. In this sense, we aimed to determine the periods of weed interference in the cowpea crop in the semi-arid region of Minas Gerais. The treatments were arranged in a 2 x 10 factorial scheme, with two factors: coexistence and control of weed and ten periods: 0, 7, 14, 21, 28, 35, 42, 49, 56 and 63 days after emergence (DAE) subjected to control and coexistence. The evaluated characteristics were dry weight of weeds and the cowpea, weight of 100 grains and yield, which was fitted to the exponential model and the periods of interference of the weed community were determined. The period before interference (PBI) occurred up to $20 \mathrm{DAE}$, with weed control having to be performed up to $32 \mathrm{DAE}$. The critical period for weed control (CPWC) was from 21 to 32 days after emergence of the crop. The cowpea bean yield reduced $73.5 \%$ with the weed interactions during the whole cycle, under conditions of the semi-arid of Minas Gerais.

Key words: BRS Itaim; competition; Vigna unguiculata

\section{Períodos de interferência de plantas daninhas na cultura do feijão-caupi}

\section{no semiárido mineiro}

RESUMO: A interferência de plantas daninhas é um dos principais fatores que limitam a produtividade de feijão-caupi. Neste sentido, objetivou-se determinar os períodos de interferência de plantas daninhas na cultura do feijão-caupi no semiárido mineiro. Os tratamentos foram arranjados em esquema fatorial $2 \times 10$, sendo dois fatores: convivência e controle das plantas daninhas e dez períodos: $0,7,14,21,28,35,42,49,56$ e 63 dias após a emergência (DAE) submetidos a controle e convívio. As características avaliadas foram massa da matéria seca das plantas daninhas e do feijão-caupi, massa de 100 grãos e produtividade que foi ajustada ao modelo exponencial e determinou-se os períodos de interferência da comunidade infestante. 0 período anterior à interferência (PAI) ocorreu até os $20 \mathrm{DAE}$ e o controle de plantas daninhas deve ser realizado até os 32 DAE. O período crítico de prevenção à interferência (PCPI) foi de 21 a $32 \mathrm{DAE}$ da cultura. A produtividade de feijão-caupi é reduzida em 73,5\% com o convívio de plantas daninhas durante todo ciclo, em condições de cultivo do semiárido mineiro.

Palavras-chave: BRS Itaim; competição; Vigna unguiculata 


\section{Introduction}

Brazil is among the main producers and consumers of cowpea (Vigna unguiculata), however, the national average yield is around $521 \mathrm{~kg} \mathrm{ha}^{-1}$ (Conab, 2020), and that is, below the crop potential, which presents a yield of above 2000 $\mathrm{kg} \mathrm{ha}^{-1}$ under experimental conditions (Guerra et al., 2017; Souza et al., 2018).

Among the yield limiting factors in this crop, interference caused by weeds is one of the problems that most negatively affects the production, as they can compete for water, light and nutrients, in addition to being hosts of pests, diseases and being able to produce allelopathic substances. These phenomena aggregate both the direct and indirect factors, and thus are characterized as interferences (Vasconcelos et al., 2012).

Weed interference in the cowpea crop can reduce yield by 64\% to 90\% (Freitas et al., 2009; Adigun et al., 2014; Osipitan, 2017; Yadav et al., 2018), depending on the management, weed species and environmental conditions. Moreover, a delay in the flowering was found, reducing nutrients absorption and biological nitrogen fixation (N), with decreased crop nodulation as well (Remison, 1978). Thus, considering the local specificities of each cultivation region, it is necessary to determine the main weed species and the appropriate time for handling them.

For that matter, the determination of interference periods is essential to increase crop yield. Studies determined the period before interference (PBI), total interference prevention (TPIP) and critical period for weed control (CPWC) in several crops (Oliveira et al., 2016; Tursun et al., 2016; Singh et al., 2017). However, for the cowpea crop, research is still scarce (Matos et al., 1991; Freitas et al., 2009; Adigun et al., 2014; Yadav et al., 2018) and it is necessary, mainly, for the conditions of the semi-arid region from Minas Gerais.

In this sense, these evaluations within the cultivation system of cowpea can contribute to improve the crop management and raise the production rates. Therefore, the objective was to determine the periods of interference of the weed community and to evaluate the impact on the cowpea yield in the semi-arid region of Minas Gerais.

\section{Materials and Methods}

The experiment was conducted at the Experimental Farm of the State University of Montes Claros, located in the municipality of Janaúba, MG, under the geographical coordinates of $15^{\circ} 47^{\prime} 50^{\prime \prime} \mathrm{S}, 43^{\circ} 18^{\prime} 31^{\prime \prime} \mathrm{W}$ and an altitude of $516 \mathrm{~m}$. The climate of the region is the "AW" type (tropical dry winter) (Köppen, 1948). The soil was classified as a Eutrophic Red Ultisol. All meteorological data found during the experimental period are displayed in Figure 1.

The area was prepared in a conventional manner, with a single plowing and two harrowings. Before sowing, a composite sample of soil was taken, in the $0-20 \mathrm{~cm}$ layer, for determining the chemical attributes (Table 1).

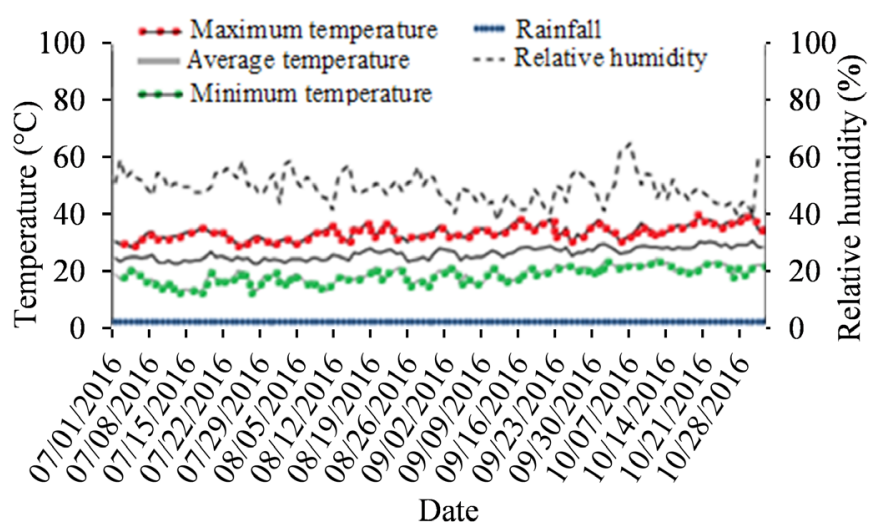

Figure 1. Maximum, average and minimum temperature, rainfall and relative humidity during the experimental period.

Table 1. Chemical analysis of the soil sample from the experimental area of the State University of Montes Claros, Janaúba campus, conducted prior to setting up the experiment. Samples collected from the $0-20 \mathrm{~cm}$ layer of soil.

\begin{tabular}{|c|c|}
\hline Characteristics & Values \\
\hline Organic Matter (dag kg-1) & 1.7 \\
\hline $\mathrm{pH}$ in water & 5.2 \\
\hline$P\left(\mathrm{mg} \mathrm{dm}^{-3}\right)$ & 30.7 \\
\hline $\mathrm{K}\left(\mathrm{mg} \mathrm{dm^{-3 }}\right)$ & 189 \\
\hline $\mathrm{Al}^{3+}\left(\mathrm{cmolc} \mathrm{dm}^{-3}\right)$ & 0 \\
\hline $\mathrm{Ca}^{2}+\left(\mathrm{cmolc} \mathrm{dm}^{-3}\right)$ & 2.3 \\
\hline $\mathrm{Mg}^{2}+\left(\mathrm{cmolc} \mathrm{dm}^{-3}\right)$ & 0.9 \\
\hline $\mathrm{Zn}\left(\mathrm{mg} \mathrm{dm} \mathrm{m}^{-3}\right)$ & 1.3 \\
\hline $\mathrm{Fe}(\mathrm{mg} \mathrm{dm}-3)$ & 28.3 \\
\hline $\operatorname{Mn}\left(\mathrm{mg} \mathrm{dm}^{-3}\right)$ & 15.8 \\
\hline $\mathrm{Cu}\left(\mathrm{mg} \mathrm{dm}{ }^{-3}\right)$ & 1.0 \\
\hline$B\left(\mathrm{mg} \mathrm{dm}^{-3}\right)$ & 0.4 \\
\hline $\mathrm{H}+\mathrm{Al}\left(\mathrm{cmolc} \mathrm{dm}^{-3}\right)$ & 1.8 \\
\hline $\mathrm{SB}+\left(\mathrm{cmolc} \mathrm{dm}^{-3}\right)$ & 3.8 \\
\hline$V(\%)$ & 68 \\
\hline $\mathrm{m}(\%)$ & 0 \\
\hline Effective CEC (cmolc dm $\mathrm{dm}^{-3}$ ) & 3.8 \\
\hline Total CEC (cmolc $\left.\mathrm{dm}^{-3}\right)$ & 5.6 \\
\hline P-rem & 43.3 \\
\hline
\end{tabular}

Fertilization was held according to the soil analysis and crop recommendation (Chagas et al., 1999), with $250 \mathrm{~kg} \mathrm{ha}^{-1}$ of the 04-30-10 NPK formulation at sowing, in addition to 40 $\mathrm{kg} \mathrm{ha}^{-1}$ of $\mathrm{N}$ in top dressing, at the V4 stage, by using urea as a nitrogen source.

After preparing the soil, a seeder-fertilizer machine was used for sowing and spreading the fertilizer in the rows. The sowing was performed in July 2016, period that presents the best climatic conditions for the crop development in Northern Minas Gerais, by placing about 15 seeds per linear meter with $0.5 \mathrm{~m}$ spaced lines.

BRS Itaim cultivar was used, which has a determined growth habit, upright size and high resistance to lodging, it also has typical, well-formed "fradinho" type grains with excellent visual appeal, with a cycle that goes from 60 to 65 days, recommended mainly for cultivation in a non-irrigated regime, due to high tolerance to water deficit (Vilarinho et al., 2010). 
The insecticides application was performed according to the crop demand, and the experiment was conducted from July to October 2016. The irrigation employed was by conventional sprinkler type, being performed according to the crop until the physiological maturity.

Treatments were arranged in a $2 \times 10$ factorial scheme, with two factors: coexistence (in the bush) and control (clean) of the weeds in the cowpea crop and 10 periods of control or coexistence. During the coexistence period, the crop was kept in the presence of weeds for ten initial growing periods: $0,7,14,21,28,35,42,49,56$ and 63 days after emergence (DAE) of the crop, from which they were controlled by weekly manual weedings (Table 2). The experimental design was a randomized block with four replicates. Plots were composed of six rows of bean plants, spaced $0.5 \mathrm{~m}$ apart, with $4 \mathrm{~m}$ in length and occupying an area of $12 \mathrm{~m}^{2}$ (4 x $3 \mathrm{~m}$ ).

During the control period, the crop was kept free of weeds in the same previously described periods and the weeds which emerged after these intervals were no longer controlled until the crop harvest, at 63 DAE. The experimental units were kept free from weed interference by weekly manual weedings, after each coexistence period.

The evaluated characteristics were dry matter weight (DMW) of weeds and cowpea plants, weight of 100 grains and yield of cowpea grains, with humidity corrected to $13 \%$, expressed in $\mathrm{kg} \mathrm{ha}^{-1}$. The complete structure of weeds was collected, containing both root system and shoot. For evaluating the DMW in the bean plants, four plants per plot were collected in the useful area. For collecting weeds at 0,7 , $14,21,28,35,42,49,56$ and $63 \mathrm{DAE}$, the standard method of the square survey $(0.5 \mathrm{~m} \times 0.5 \mathrm{~m})$ was employed, which was then randomly set once in the useful area of each plot, collecting all the plants, as described by Braun-Blanquet (1979) and Erasmo et al. (2004).

For analyzing the DMW from the samples of weeds and bean plants, they were placed in paper bags and dried in an oven with forced air circulation at $70 \stackrel{\circ}{\circ}$, until attaining constant mass. To obtain the grain yield of each plot, the two central rows were harvested and the moisture content of the grain weight was corrected to $13 \%$.

Table 2. Description of the experimental treatments.

\begin{tabular}{cccc}
\hline Treatments $^{1}$ & $\begin{array}{c}\text { Coexistence } \\
\text { period (DAE) }\end{array}$ & Treatments $^{2}$ & $\begin{array}{c}\text { Control } \\
\text { periods } \\
\text { (DAE) }\end{array}$ \\
\hline 1 & 0 & 11 & 0 \\
2 & $0---7$ & 12 & $0---7$ \\
3 & $0---14$ & 13 & $0---14$ \\
4 & $0---21$ & 14 & $0---21$ \\
5 & $0---28$ & 15 & $0---28$ \\
6 & $0---35$ & 16 & $0---35$ \\
7 & $0---42$ & 17 & $0---42$ \\
8 & $0---49$ & 18 & $0---49$ \\
9 & $0---56$ & 19 & $0---56$ \\
10 & $0---63$ & 20 & $0--63$ \\
\hline
\end{tabular}

${ }^{1}$ Treatments 1 - 10 Group kept in coexistence with weeds (wild grass). ${ }^{2}$ Treatments 11 - 20 Group kept free from weeds (clear). DAE - Days After Emergence.
For the weeds DMW, these plants were described as a function of DAEs. Yield and DMW data of the bean (shoot + roots) were submitted to regression analysis and the models choice considered the significance of the beta coefficients by the $t$ test; the coefficient of determination magnitude; the smallest difference between $R^{2}$ and adjusted $R^{2}$ and the adequacy of the model to the studied biological phenomenon.

Regarding yield data, the adopted model was the exponential: $Y=a /[1+\exp (-(x+b) / c)]$, where: $Y=$ grain yield, $x$ = number of days after bean crop emergence; $a=$ maximum yield obtained in the clean control; $b=$ number of days on which $50 \%$ of the reduction in maximum yield occurred; and $c=$ slope of the curve. Afterwards, the period before interference (PBI), total period of interference prevention (TPIP) and critical period for weed control (CPWC) of weeds in the cowpea crop were determined. Based on the regression equations, the periods of interference of the infesting community on the bean crop were then determined, by subtracting $5 \%$ from the maximum estimated yield in the regression equations in relation to the treatment kept in the infestation absence, a value considered as the cost of adopting chemical control.

\section{Results and Discussion}

The composition of the weed community that occurred during the experiment conduction presented 15 species, distributed in 8 families and 15 genera. The families and species found were Amaranthaceae: Amaranthus viridis (Caruru); Asteraceae: Bidens pilosa (Picão-preto), Acanthospermum hispidum (Carrapicho-de-carneiro), Blainvillea latifolia (Erva-palha); Commelinaceae: Commelina benghalensis (Trapoeraba); Convolvulaceae: Ipomoea grandifolia (Corda-deviola); Fabaceae: Senna obtusifolia (Mata-pasto); Malvaceae: Malva sylvestris (Malva), Malvastrum coromandelianum (Guanxuma); Poaceae: Brachiaria plantaginea (Capimmarmelada), Cenchrus echinatus (Capim-carrapicho), Eleusine indica (Capim-pé-de-galinha), Axonopus purpusii (Capimmimoso), Dactyloctenium aegyptium (Capim-mão-de-sapo); Portulacaceae: Portulaca oleracea (Beldroega).

Weeds are consistent with other surveys conducted in the studied region (Batista et al. 2016; Batista et al. 2017; Guerra et al., 2017) indicating a seed bank in the soil where some species stand out in relation to others depending on weather conditions and cultivated crop.

An increase in weed density was noted from 21 DAE onwards, surpassing 1,000 individuals per $\mathrm{m}^{2}$ with a subsequent decline in density and an increase in dry matter weight from 35 to $42 \mathrm{DAE}$, reaching more than $1,000 \mathrm{~g} \mathrm{~m}^{-2}$ (Figure $2 \mathrm{~A}$ and $\mathrm{B}$ ). This result is no doubt related to the short life cycle of some species in the weed community, which provides the possibility of renewing some plants during the crop cycle. The short cycle of some weed species is a survival mechanism due to adverse environmental conditions and is associated with the short rainy season in semi-arid regions (Silva \& Silva, 2007). 


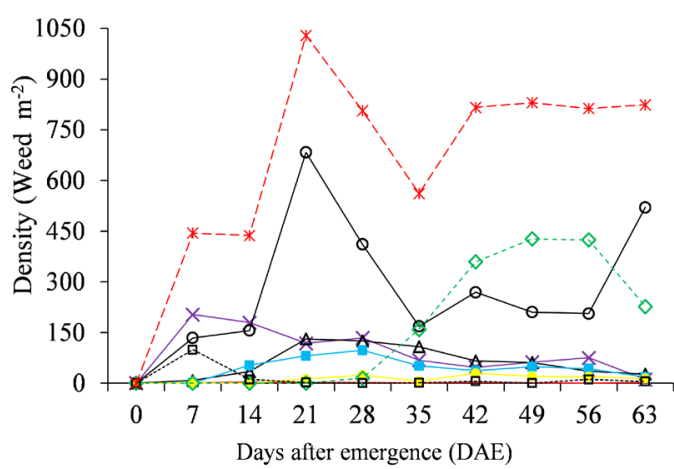

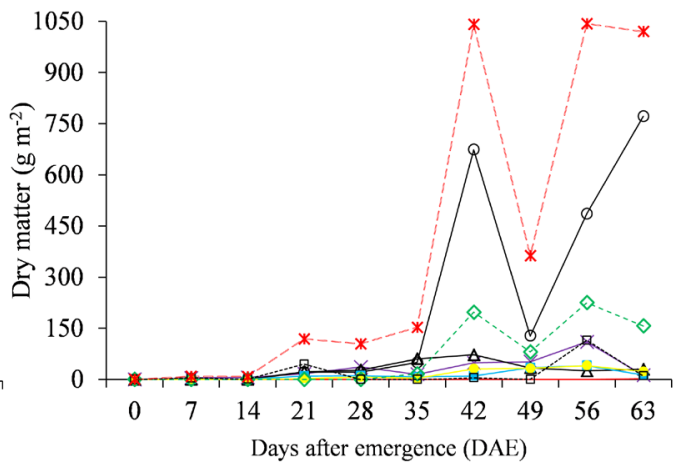

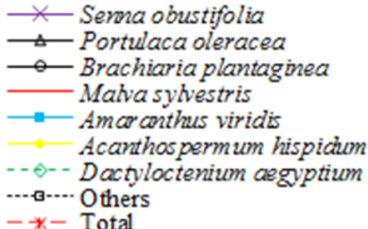

Figure 2. Density (A) and dry matter weight (shoot + roots) (B) from the main weed species during the lifecycle of the cowpea cv. BRS Itaim, grown in the fall-winter crop of 2016.

Weed community surveys in areas with cowpea cultivation in Northern Minas Gerais indicate a predominance of plants from the Poaceae family (Batista et al., 2016), as well as found in the present study, where Brachiaria plantaginea (Capimmarmelada) and Dactyloctenium aegyptium (Capim-mão-desapo) had the highest density and, consequently, the highest weight at the end of the experiment.

Due to the environmental conditions with high temperatures (Figure 1) and intense solar radiation, under irrigated conditions, the development of the weeds from the Poaceae family is favored. Hence, B. plantaginea and $D$. aegyptium show rapid initial growth and vigorous canopy, which then intensifies interspecific and intraspecific competition and makes them dominant, especially those that germinated and emerged at the beginning of the cowpea cycle (Manabe et al., 2015).

Results of the weight of 100 grains of cowpea showed no difference between treatments, but the periods of control (clean) and coexistence (in the bush) showed an overall mean of 23.94 and $24.22 \mathrm{~g}$, respectively. Freitas et al. (2009), when evaluating weed interference in cowpea also did not identify difference in the weight of 100 grains in treatments with and without weed coexistence, reporting that this characteristic is inherent of the cultivar.

Values of dry weight (shoot + roots) of cowpea were fitted to the cubic model in function of the evaluated DAEs (Figure 3). At point zero DAE, that is, when the bean plants were not subjected to coexistence and there was no weed controlling, both of them throughout the cycle, the dry weight of cowpea was 98 and $45 \mathrm{~g}$, respectively. Subsequently, both in conditions of coexistence and control at 7 and 14 DAE of weeds, there was a decline followed by a subsequent increase with greater accumulation of dry weight in cowpea plants at $56 \mathrm{DAE}$, and decrease at $63 \mathrm{DAE}\left(98 \mathrm{~g} \mathrm{~m}^{-2}\right)$, due to the cultivar

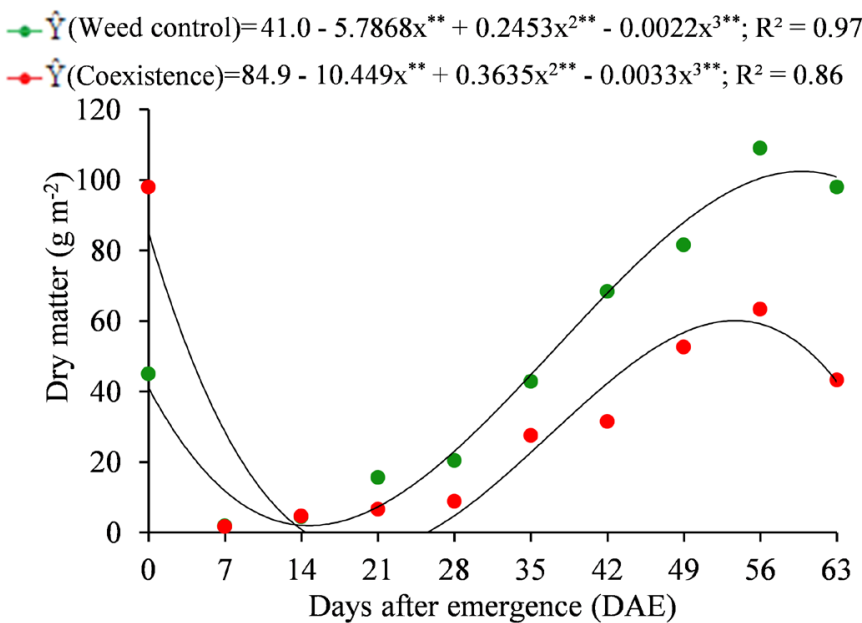

Figure 3. Dry matter weigh (shoot + roots) of cowpea bean cv. BRS Itaim, in the fall-winter crop of 2016 in function of the days after emergence (DAE) of the weeds.

being at the end of its cycle. This decrease is expected since the photoassimilates were directed to the production of pods that become the preferred drain of the plant (Linhares et al., 2014; Souza et al., 2017).

From the cowpea grain yield, obtained in the different periods of weed control and coexistence with the crop, the period before interference (PBI) was determined, and the crop productivity in the weed-free period is possible determination of the total period of interference prevention (TPIP) (Figure 4).

Grain productivity related to the weed treatment during the whole cycle decreased by $73.5 \%$ in comparison to the treatment kept entirely clean, assuming a $5 \%$ loss in grain yield. The acceptable loss due to weed interference in the bean grain yield is variable for each situation, depending on the controlling cost, yield gain and market value of the product. 


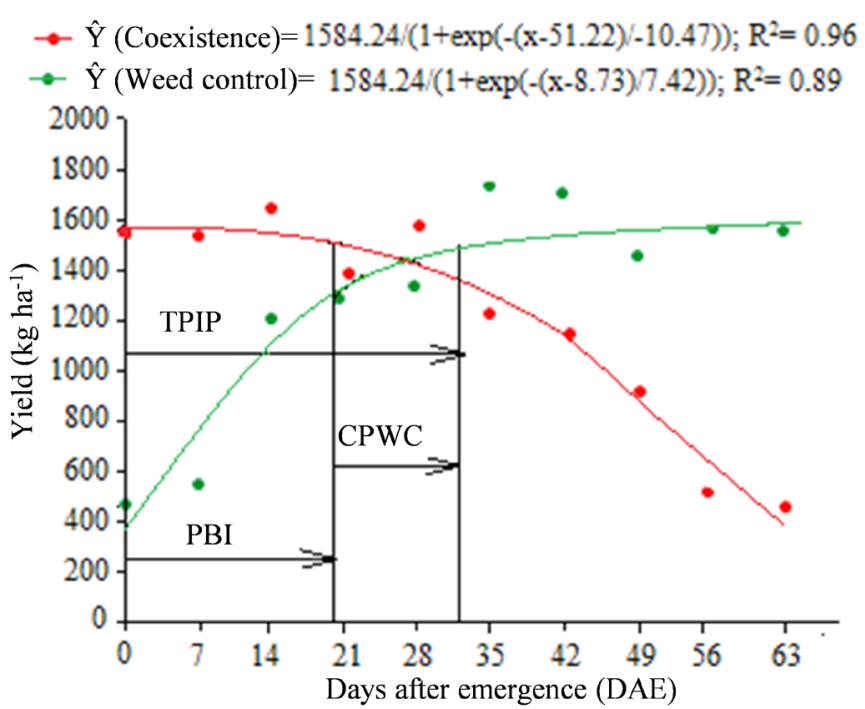

Figure 4. Yield of cowpea bean with determination of the period before interference (PBI), total period of prevention of interference (TPIP) and critical period of prevention of interference (CPIP) of weeds in the crop as a function of the control periods (clean) and coexistence (in the bush).

The reduction in grain yield due to weed interference throughout the cowpea cycle is quite variable in several studies, with values of $64 \%$ (Yadav et al., 2018), 66\% (Gonzaga et al., 2018), 68\% (Adigun et al., 2014) and up to $90 \%$ (Freitas et al., 2009). For phaseolus species, this same trend in reducing yield happens (Frenda et al., 2013; Esmaeilzadeh \& Aminpanah, 2015; Odero \& Wright, 2018). Therefore, the results of the present study show the importance of adjustments to local specificities, as the reduction in yield is dependent on several factors, such as weed community, cultivar, cultivation conditions and edaphoclimatic characteristics of each region.

The period before interference (PBI) occurred until 20 DAE. For avoiding yield losses, weeds must be controlled until $32 \mathrm{DAE}$, with this being the total period of interference prevention (TPIP). PBI is the period in which the weeds occurrence does not cause yield losses in the cowpea, since, in the initial stages, both the crop and the weeds have an adequate amount of environmental resources, such as light, nutrients and water.

The period between the PBI and the TPIP is the critical period for weed control (CPWC), and it was from 20 to 32 DAE. Therefore, weeds increased their leaf area and root system and started to compete for the environmental resources and, thus, controlling the weed community becomes essential for greater development and yield of cowpea.

There is a wide variation in the weed controlling periods in cowpea crop, with examples of 0-36 DAE (Matos et al., 1991), 11-35 DAE (Freitas et al., 2009), 25-57 DAE (Yadav et al., 2018). In the present study, the period indicated for applying weed control, that is, CPWC from 20 to $32 \mathrm{DAE}$, was influenced by the growth dynamics of the main species present in the area, where there was an increase in density and greater accumulation of dry weight of weeds at 21 and 35 DAE, respectively.
The maximum grain yield, obtained by treatments that were not affected by weed interference corresponded to $1,732 \mathrm{~kg} \mathrm{ha}^{-1}$, and thus, within the expected for the BRS Itaim cultivar, corroborating with the yield values of previous studies in the studied region (Souza et al., 2018). However, with weed interference throughout the cycle, the lowest yield (458 $\mathrm{kg} \mathrm{ha}^{-1}$ ) was found, which is close to the national mean yield of $558 \mathrm{~kg} \mathrm{ha}^{-1}$ (Conab, 2018). In this context, the negative influence exerted by weeds in reducing the yield of cowpea is clearly evidenced.

Moreover, the results of the present study expand the existing knowledge about the weed community dynamics. Associating them with other research results (Batista et al., 2016; Batista et al. 2017; Guerra et al., 2017; Souza et al., 2018) allow an extrapolation for optimizing management practices and increasing the production rates of cowpea in the edaphoclimatic conditions of the semi-arid region of Minas Gerais.

\section{Conclusions}

The period before the interference (PBI) occurred until 20 $\mathrm{DAE}$, and the weed control must be performed until $32 \mathrm{DAE}$, since after that period the weeds occurrence does not cause losses in the cowpea yield.

The critical period for weed control (CPWC) was from 21 to 32 days after the crop emergence.

Cowpea yield reduces by $73.5 \%$ when coexisting with weeds throughout its cycle, under the semi-arid cultivation conditions.

\section{Acknowledgment}

The authors would like to thank FAPEMIG and CAPES for granting scholarships. This study was conducted with the support of the Coordination for the Improvement of Higher Education Personnel - Brazil (CAPES) - Financing Code 001.

\section{Literature Cited}

Adigun, J.; Osipitan, A. O.; Lagoke, S. T.; Adeyemi, R. O.; Afolami, S. $\mathrm{O}$. Growth and yield performance of cowpea (Vigna unguiculata (L.) Walp) as influenced by row-spacing and period of weed interference in South-West Nigeria. Journal of Agricultural Science, v. 6, n. 4, p. 188-198, 2014. https://doi.org/10.5539/jas. v6n4p188.

Batista, P. S. C.; Oliveira, V. S.; Caxito, A. M.; Carvalho, A. J.; Aspiazú, I. Phytosociological survey of weeds in cultivars of common beans with different types of growth in the north of Minas Gerais. Planta Daninha, v. 34, n. 3, p.497-507, 2016. https://doi.org/10.1590/ s0100-83582016340300010.

Batista, P. S. C.; Oliveira, V. S.; Souza, V. B.; Carvalho, A. J.; Aspiazú, I. Phytosociological survey of weeds in erect prostrate cowpea cultivars. Planta Daninha, v. 35, e017160273, 2017. https://doi. org/10.1590/s0100-83582017350100031. 
Braun-Blanquet, J. Fitossociologia: bases para el estudio de las comunidades vegetales. Madrid: H. Blume, 1979. 820 p.

Chagas, J.M.; Braga, J.M.; Vieira, C.; Salgado, L.T.; Junqueira Neto, A.; Araújo, G.A. de A.; Andrade, M.J.B. de; Lana, R.M.Q.; Ribeiro, A.C. Feijão. In: Ribeiro, A. C.; Guimarães, P. T. G.; Alvarez, V. H. (Eds.). Recomendações para o uso de corretivos e fertilizantes em Minas Gerais: 5a Aproximação. Viçosa: Comissão de Fertilidade do Solo do Estado de Minas Gerais, 1999. p. 274-275.

Companhia Nacional de Abastecimento - Conab. Acompanhamento da safra brasileira de grãos, v. 7 - Safra 2019/20 - Sétimo levantamento, Brasília, p. 1-25, 2020. https://www.conab.gov.br/info-agro/safras/ graos/boletim-da-safra-de-graos. 08 de Abril de 2020.

Erasmo, E. A. L.; Pinheiro, L. L. A.; Costa, N. V. Levantamento fitossociológico das comunidades de plantas infestantes em áreas de produção de arroz irrigado cultivado sob diferentes sistemas de manejo. Planta Daninha, v. 22, n. 2, p. 195-201, 2004. https://doi.org/10.1590/S0100-83582004000200004.

Esmaeilzadeh, S.; Aminpanah, H. Effects of planting date and spatial arrangement on common bean (Phaseolus vulgaris) yield under weed-free and weedy conditions. Planta Daninha, v. 33 , n. 3, p. 425-432, 2015. https://doi.org/10.1590/S010083582015000300005.

Freitas, F. C. L.; Medeiros, V. F. L. P.; Grangeiro, L. C.; Silva, M. G. O.; Nascimento, P. G. M. L.; Nunes, G.H. Interferência de plantas daninhas na cultura do feijão-caupi. Planta Daninha, v. 27 , n. 2 , p. 241-247, 2009. https://doi.org/10.1590/S010083582009000200005.

Frenda, A.S.; Ruisi, P.; Saia, S.; Frangipane, B.; Di Miceli, G.; Amato, G.; Giambalvo, D. The critical period of weed control in faba bean and chickpea in Mediterranean areas. Weed Science, v. 61, n. 3, p. 452-459, 2013. https://doi.org/10.1614/WS-D-12-00137.1.

Gonzaga, G. da S.; Cruz, A. B. S. de.; Albuquerque, J. A. A.; Santos, G. X. L. dos.; Soares, M. B. B.; Rocha, P. R. R; Alves, J. M. A.; Castro, T. S. de.; Santos, T. S. Dos.; Cruz, D. L. S de. Phytosociology of weed community in culture of cowpea (Vigna unguiculata L. Walp) and controlling possibilities with pre-emergent herbicides. Applied Ecology and Environmental Research, v. 16, n. 5, p. 5311-5322, 2018. https://doi.org/10.15666/aeer/1605_53115322.

Guerra, J. V. S.; Carvalho, A. J. de.; Medeiros, J. C.; Souza, A. A. de.; Brito, O. G. Agronomic performance of erect and semierect cowpea genotypes in the north of Minas Gerais, Brazil. Revista Caatinga, v. 30, n. 1, p. 679-686, 2017. https://doi. org/10.1590/1983-21252017v30n316rc.

Köppen, W. Climatologia: con un estudio de los climas de la tierra. Mexico: Fondo de Cultura Econômica, 1948. 478 p.

Linhares, C. M. de S.; Freitas, F. C. L. de.; Silva, K. de S.; Lima, M. F. P. de.; Dombroski, J. L. D. Crescimento do feijão-caupi sob efeito dos herbicidas fomesafen e bentazon+imazamox. Revista Caatinga, v. 27, n. 1, p. 41- 49, 2014. https://periodicos.ufersa.edu.br/index. php/caatinga/article/view/2572/pdf_84. 12 Out. 2018.

Manabe, P. M. S. Matos, C. C.; Ferreira, E. A.; Silva, A. F.; Silva, A. A.; Sediyama, T.; Manabe, A.; Rocha, P. R. R.; Silva, C. T. Efeito da competição de plantas daninhas na cultura do feijoeiro. Bioscience Journal, v. 31, n. 2, p. 333-343, 2015. https://doi. org/10.14393/bj-v31n2a2015-22271.
Matos, V. P.; Silva, R. F.; Vieira, C.; Silva, J. F. Período crítico de competição entre plantas daninhas e a cultura do caupi. Pesquisa Agropecuária Brasileira, v. 26, n. 5, p. 737-743, 1991. https://seer. sct.embrapa.br/index.php/pab/article/view/3398/731. 18 Jan. 2019.

Odero, D. C.; Wright, A. L. Critical Period of Weed Control in Snap Bean on Organic Soils in South Florida. Hort Science, v. 53, n. 8, p. 1129-1132, 2018. https://doi.org/10.21273/HORTSCI12536-17.

Oliveira, R. M.; Aspiazú, I.; Silva, K. M. de J.; Portugal, A. F.; Silva, A. F.; Carvalho, A. J. de. Interferência de plantas daninhas em sorgo sacarino em diferentes espaçamentos no semiárido mineiro. Revista Brasileira de Milho e Sorgo, v. 15, n. 3, p. 481-489, 2016. https://doi.org/10.18512/1980-6477/rbms.v15n3p481-489.

Osipitan, O. A. Weed Interference and Control in Cowpea Production: A Review. Journal of Agricultural Science, v. 9, n. 12, p. 11-20, 2017. https://doi.org/10.5539/jas.v9n12p11.

Remison, S. U. The performance of cowpea (Vigna unguiculata (L.) Walp) as influenced by weed competition. The Journal of Agricultural Science, v. 90, n. 3, p. 523-530, 1978. https://doi. org/10.1017/s002185960005604.

Silva, A. A. Silva, J. F. Biologia de plantas daninhas. In: Silva, A. A.; Silva, J. F. Tópicos em manejo de plantas daninhas. Viçosa: Universidade Federal de Viçosa, 2007. p. 17-61.

Singh, M.; Bhullar, M. S.; Chauhan, B.S. Relative time of weed and crop emergence is crucial for managing weed seed production: A study under an aerobic rice system. Crop Protection, v. 99, n. 1, p. 33-38, 2017. https://doi.org/10.1016/j.cropro.2017.05.013.

Souza, P. J. de O. P. de.; Farias, V. D. da S.; Lima, M. J. A. de.; Ramos, T. F.; Sousa, A. M. L. de. Cowpea leaf area, biomass production and productivity under different water regimes in castanhal, Pará, Brazil. Revista Caatinga, v. 30, n. 3, p. 748-759, 2017. https://doi. org/10.1590/1983-21252017v30n323rc.

Souza, V. B. de.; Carvalho, A. J. de.; Silva, K. J. D.; Rocha, M. de M.; Lacerda, M. L.; Pereira Filho, I. A. Agronomic performance of cowpea elite lines in the states of Minas Gerais and Mato Grosso, Brazil. Revista Caatinga, v. 31, n. 1, p. 90-98, 2018. https://doi. org/10.1590/1983-21252018v31n111rc.

Tursun, N.; Datta, A.; Sakinmaz, M. S.; Kantarci, Z.; Knezevic, S. Z.; Chauhan, B. S. The critical period for weed control in three corn (Zea mays L.) types. Crop Protection, v. 90, n.1, p. 59-65, 2016. https://doi.org/10.1016/j.cropro.2016.08.019.

Vasconcelos, M. C. C.; Silva, A. F. A.; Lima, R. S. Interferência de plantas daninhas sobre plantas cultivadas. Agropecuária Científica no Semi-Árido, v. 8, n.1, p. 1-6, 2012. http://revistas.ufcg.edu.br/ acsa/index.php/ACSA/article/view/159/pdf. 07 Jan. 2019.

Vilarinho, A. A.; Rocha, M. de M.; Freire Filho, F. R.; Coelho, G. BRS Itaim - cultivar de feijão-caupi com grãos tipo fradinho. Boa Vista: Embrapa Roraima, 2010. 4p. (Embrapa Roraima. Comunicado Técnico, 58). http://ainfo.cnptia.embrapa.br/digital/bitstream/ item/44867/1/COT-58-2010-ID-90.pdf. 16 Jan. 2019.

Yadav, T.; Chopra, N. K.; Chopra, N. K.; Kumar, R.; Soni, P. G. Assessment of critical period of crop-weed competition in forage cowpea (Vigna unguiculata) and its effect on seed yield and quality. Indian Journal of Agronomy, v. 63, n. 1, p. 124-127, 2018. http://www.indianjournals.com/ijor.aspx?target=ijor:ija\&volum e=63\&issue=1\&article=023. 07 Jan. 2019. 